Yüzüncü Y1 Üniversitesi
Tarim Bilimleri Dergisi

Araştırma Makalesi (Research Article)

Investigation of Socio-Economic Characteristics of Wheat Producers on Certified Seed Use: The Case of Ankara Province**

\author{
Celal CEVHER ${ }^{* 1}$, Bülent ALTUNKAYNAK ${ }^{2}$ \\ ${ }^{1}$ Fields Crop Central Research Institute, Ankara, Turkey \\ ${ }^{2}$ Gazi University, Faculty of Science, Department of Statistics, Ankara, Turkey \\ ${ }^{1}$ https://orcid.org/0000-0002-3631-0321 2https://orcid.org/0000-0002-7571-2155 \\ *Corresponding author: celal.cevher@tarimorman.gov.tr
}

\section{Article Info}

Received: 27.11.2019

Accepted: 04.03.2020

Online Published 31.03.2020

DOI: $10.29133 /$ yyutbd.651446

Keywords

Ankara,

Productivity,

Socio-economic factors,

Wheat production

\begin{abstract}
The aim of this study is to determine the socio-economic factors affecting the use of certified seeds. By determining these factors, it is aimed to increase the income level and thus the welfare of farmers. In addition, by increasing the use of certified seeds, it is desired to obtain quality wheat production and contribute to the development of the grain industry. In the study, producers' opinions on certified seed use were examined in terms of socio-economic variables. As a research area, Ankara province, where certified seed use is common (approximately 20\%), was chosen. Land size was taken into account in determining the sampling volume. The primary data of the study were collected by questionnaire method from 318 manufacturers. Secondary data was obtained from agricultural organizations. According to the results of the research, the rate of adoption of certified wheat seed was determined as $58.7 \%$. $90.6 \%$ of the producers stated that the seed support given was not sufficient and $88.7 \%$ of the seed prices were high. The rate of producers stating that there are suitable alternative seed varieties in the research area is $83.6 \%$. It has been determined that the training level of the producers has a significant impact $(\mathrm{p}<0.05)$ on the adequacy of the supports and their opinions on seed prices. The producer's residence and income levels have had a significant $(\mathrm{p}<0.05)$ effect on alternative seed selection. As a result, it has been concluded that certified seed support provided by the Ministry of Agriculture and Forestry affects quality seed use, increase in gross production value and decrease in production costs.
\end{abstract}

\title{
Buğday Üreticilerinin Sertifikalı Tohum Kullanımına Etki Eden Sosyo-Ekonomik Özelliklerin İncelenmesi: Ankara İli Örneği
}

\section{Makale Bilgileri}

Geliş: 27.11.2019

Kabul: 04.03.2020

Online Yayınlanma 31.03.2020

DOI: $10.29133 /$ yyutbd.651446

\section{Anahtar kelimeler}

Ankara,

Verimlilik,

Sosyo-ekonomik faktörler,

Buğday üretimi
Öz: Bu çalışmanın amacı, sertifikalı tohum kullanımına etki eden sosyo-ekonomik faktörlerin belirlenmesidir. Bu faktörlerin belirlenmesi ile çiftçilerin gelir düzeyinin ve dolaysıyla refahının yükseltilmesi amaçlanmaktadır. Ayrıca, sertifikalı tohum kullanımın arttırılmasıyla kaliteli buğday üretiminin elde edilmesi ve hububat sanayinin gelişmesine katkı sağlaması istenmektedir. Çalışmada, üreticilerin sertifikalı tohum kullanımına ilişkin görüşleri sosyo-ekonomik değişkenler bakımından incelenmiştir. Araştırma alanı olarak, sertifikalı tohum kullanımın yaygın olduğu (yaklaşık \%20) Ankara ili seçilmiştir. Örnekleme hacminin belirlenmesinde arazi genişliği dikkate alınmıştır. Çalışmanın birincil verileri 318 üreticiden anket yöntemi ile toplanmıştır. İkincil veriler tarımsal kuruluşlardan sağlanmıştır. Araştırma sonuçlarına göre, sertifikalı buğday tohumunun benimsenme oranı \%58.7 olarak belirlenmiştir. Üreticilerin \%90.6's1 
verilen tohum desteğinin yeterli olmadığını, \%88.7'sinin ise tohum fiyatlarının yüksek olduğunu belirtmişlerdir. Araştırma alanında uygun alternatif tohum çeşitlerinin olduğunu belirten üreticilerin oranı \%83.6'dır. Üreticilerin eğitim düzeyinin, desteklerin yeterliliği ve tohum fiyatlarına ilişkin görüşleri üzerinde önemli etkiye sahip $(\mathrm{p}<0.05)$ olduğu tespit edilmiştir. Üreticinin ikamet yeri ve gelir düzeyi, alternatif tohum seçimi üzerinde önemli $(\mathrm{p}<0.05)$ bir etkiye sahip bulunmuştur. Sonuç olarak, Tarım ve Orman Bakanlığ 1 tarafından verilen sertifikalı tohum desteğinin, kaliteli tohum kullanımına, gayrisafi üretim değerindeki artışa ve üretim masraflarındaki azalmaya etki yaptığı sonucuna ulaşılmıştır.

**This article was presented orally at AGROFOOD (20-21 June 2019) congress.

\section{Introduction}

Wheat is one of the basic nutrients in human nutrition. For this reason, it is ranked first among the cultivated crops in terms of production. In Turkey, 23.4 million hectares of agricultural activity is carried out. about $71 \%$ of these areas produce cereals. Among the grain cultivation areas, wheat ranks first with a share of $69 \%$. The quality of the wheat having a very large production rate in Turkey is still not at the desired level. Wheat yield is 2630 ton/ha in Turkey and it is considerably below the world average (3 400 ton/ha) (Anonymous, 2018).Therefore, the use of certified seeds is important in increasing the quality and yield in wheat production. With the use of certified wheat seeds, the income level of farmers can be increased. For this reason, certified seed use of farmers should be encouraged. It has been known that to increase wheat yield is important to development of quality varieties, resistant to adverse environmental conditions and with high yield (Şehirali and Özgen, 2013). In another study, efficient and high quality varieties are recommended for producers and the provision of seed production is essential for sustainable grain production (Olgun et al., 2012). A large portion of wheat production in Turkey is carried out in dry conditions. Therefore, wheat producer's agricultural production income is lower than other producers (Cevher, 2015). The most basic way to increase the quality of wheat is to use high quality seeds. In wheat production, seed costs ranges between $8.26 \%$ and $25.78 \%$ of total input costs (Adanacioğlu and Engindeniz, 2011). In Turkey, agricultural productivity is low, production is carried out with high costs (Tuğay, 2012). More products can be obtained with the use of certified seeds (Kronstad, W.E., 1998; Bishaw et al., 2007; Tester and Langridge, 2010; Engin, 2015; Anonymous, 2017).

In terms of food safety, seed is an important factor in plant production. The nature of the seeds used by the producers is important in the production, quality and efficiency increase (Yağdı et al., 2010). Newly developed seeds are seen as an important innovation for small producers with limited resources (Lanteri and Quagliotti, 1997; Hazneci and Ceyhan, 2017). When studies in other countries have examined, for example; the use of certified seeds is one of the main factors in terms of efficiency in wheat production, quality and raising farm income (Sofijanova et al., 2012). The use of certified seeds is important for the development of the country's economy and for social welfare (Jaffee and Srivastava, 1994; Anonymous, 2001; Laurance et al., 2014). The average yield obtained from the use of certified seeds in wheat production was determined to be $22.5 \%$ higher than non-certified seeds (Sofijanova et al., 2012). In a study conducted in Nigeria, it was determined that the certified rice seed support given to the producers increased the production by $18.5 \%$. This has contributed to increased producer income, quality certified seed access and rural poverty reduction (Awotide et al., 2011). Agricultural input prices in Turkey are relatively high compared to other countries. This situation prevents small producers to buy quality seeds (Aksoy et al., 2017). The availability of certified seed prices and informing producers about the advantages of agricultural production can be significantly increased (Erdem and Yücel, 2015). Agricultural support policies should be given priority to the production and distribution of seed varieties with high efficiency (Erdem, 2012).

Agricultural production has not reached the desired level of quality, due to changing agricultural policies in Turkey. In this context, support policies can be directed taking into account the socioeconomic and farms characteristics of the producers (Kızılaslan, 2004; İpekçioğlu et al., 2014). Seed production activities to increase the yield and quality in plant production is on the way to becoming an important sector (Şahin et al., 2013). Producers should be informed about certified seed, fertilization and spraying (Başaran and Engindeniz, 2015). In order to increase the adoption of newly developed 
varieties by producers, training and extension activities should be carried out regularly. It was also stated that producers should be informed about the benefits of innovations (Kaynak and Boz, 2015). In another study, it was found that $55 \%$ of neighbors and relatives, agriculture directorates and Agriculture Chamber Presidencies were $10 \%$ effective in adopting agricultural innovations (Yüksel, 2009). It is determined that the producers prefer the variety of their experiences and then apply to the seed dealers (Adalığlu et al., 2017). If the work of dissemination organizations is in line with agricultural policies, adoption of extension proposals will be more effective. (Boyac1 and Y1ldiz, 2014). In another study, it is determined that the decisions taken in agricultural production vary according to market conditions, farm or producer characteristics (Osteen et al., 2012). It was determined that the experience of the producers was more influential in the choice of varieties, followed by seed dealers (Adalığlu et al., 2017).

Producers in Turkey have been supported since 2004 for the use of certified wheat seeds. However, there are a few studies to measure the results of the supports given by the government from a numerical point of view. In this study, the effect of the supports given to the use of certified seeds on the socio-economic status of the producer has been examined. In the study, the following research questions were sought; i) Do supports for certified seed use increase the production significantly? ii) Do changes in productivity depends on the socio-economic characteristics of the producers?

\section{Materials and Methods}

\subsection{The model}

The research was carried out to determine the effect of the producers' socio-economic characteristics on certified seed use. The socioeconomic variables discussed in the study show parallels with the previous studies on this subject in terms of variables. (La Due et al., 1991; Hennessy and O'Brien, 2008). These variables include age, education level, residence status of the producer, membership status of off-farm income, farm income and agricultural institutions.

\subsection{Data and sampling}

The main material of the study consisted of the data obtained from the producers used certified wheat seeds and received government supports in Ankara. Ankara is one of Turkey's leading province in terms of crop production. The most important plant produced in the field agriculture is wheat. The most important use of certified seeds of wheat stock and most of the provinces in Turkey beginning comes Ankara. In addition, Ankara province has been selected because it is the location of certified wheat seed companies and General Directorate of Agricultural Enterprises (TIGEM), as well as the presence of research institutes where wheat breeding works are most common. The stratified sampling method was used in the study because of the fact that the land size is not homogeneous and the number of the districts is represented in the study. The formula given below is used to determine the sample size (Yamane, 2001).

$$
n_{h}=\frac{N_{h} S_{h}}{\sum N_{h} S_{h}} n
$$

The number of farmers who would be interviewed was set to 318 as a result of the calculation. Sample size was determined to be 318 farmers (60 in Bala, 45 in Gölbaş1, 52 in Haymana, 149 in Polatl1, and 12 in Şereflikoçhisar). The survey was conducted through face-to-face interviews between October and November 2018.

\subsection{Data and variables}

The variables used in the study are given in Table 1 with their definitions. These variables are the most likely to affect certified seed use and support utilization (Cevher and Altunkaynak, 2019). 
Table 1. Variables and their descriptions

\begin{tabular}{ll}
\hline Variable & Defination \\
\hline Producers' education & $1=$ Primary, 2=Middleschool, 3=High school, 4=University \\
Place of residence & $1=$ Rural, $2=$ City \\
Off-farmincome & $1=$ No, $0=$ Yes \\
Annual income status & $1=$ low, $2=$ medium, 3=high \\
Insufficient amount of support & $1=$ No, $0=$ Yes \\
Not enough certified seeds & $1=$ No, $0=$ Yes \\
No better certified seeds & $1=$ No, $0=$ Yes \\
Certified Seed expensive & $1=$ No, $0=$ Yes \\
\hline
\end{tabular}

\subsection{Data analysis}

In this study, logistic regression analysis is planned. However, chi-square test was used due to the absence of multicollinearity, linearity of independent variables and large sample size assumptions. The effect of socio-economic variables on the opinions of producer concerning the certified seed was investigated using chi-square test and $\mathrm{p}<0.05$ were considered to be significant.

\section{Results and Discussion}

It was found that the producers using certified seed were $19.5 \%$ of primary school, $21.4 \%$ middle school, $48.6 \%$ high school and $10.5 \%$ university graduates. According to these data, it can be said that the level of education of the producers using certified seed is high. The producers living in rural areas of $60.8 \%$ and $39.2 \%$ were living in the city center. It has been suggested that the rate of non-agricultural producers is $54.8 \%$.The ratio of low-income producers was $9.2 \%$, in middle-income group $64.0 \%$ and in high-income group $26.8 \%$. According to these results, it can be said that the income level of the producers and the non-agricultural income ratios are high. The amount of non-certified seed discarded in dry wheat production under dry conditions was determined as $210 \mathrm{~kg} /$ ha to $300 \mathrm{~kg} / \mathrm{ha}$ and an average of $235 \mathrm{~kg} / \mathrm{ha}$. The amount of certified seed used after the support was changed from $170 \mathrm{~kg} /$ ha to $250 \mathrm{~kg} /$ ha and it was found to be $210 \mathrm{~kg} / \mathrm{ha}$. In the production in irrigated area conditions, 230 $\mathrm{kg} /$ ha seed was used before the support and this amount decreased to $198 \mathrm{~kg} / \mathrm{ha}$ after support. Thus, the use of seed in dry conditions after the use of certified seed decreased by $25 \mathrm{~kg} / \mathrm{ha}$ and in irrigated conditions by $32 \mathrm{~kg} / \mathrm{ha}$. According to these results obtained, certified seed support and dissemination studies by private sector are effective in reducing the amount of seed used.

Grain producers are one of the sectors that should be supported due to their gross production values and socio-economic structures. Because the producers in this sector are disadvantaged (low gross production value, period of breeding) compared to producers in other sectors producing plants. Therefore, support policies should be determined according to the producer characteristics in this sector. In this context, the comparison of the socio-economic characteristics of producers with the adequacy of certified seed support, the amount of certified seeds, alternative seed availability and the price of seeds was analyzed statistically. The results of this research are given in the tables 2, 3, 4 and 5.

As seen in Table 2, the majority of producers (90.6\%) stated that the supports were insufficient. Those who stated that their support was insufficient were at most (98.5\%) secondary education level. It is determined that producers that do not have non-agricultural income want more support than nonagricultural producers. $95.2 \%$ of the middle income producers in terms of income level said the supports were insufficient. Different results were obtained from similar studies. In one study, $80 \%$ of the producers stated that the certified seed prices were high. Therefore, seed support should be increased and it is concluded that producers are informed about the benefits of seed (Balabanl1, 2016). The producers stated that the certified seed supports were very low and that the seed supports supplied accounted for $20 \%$ of the total seed price (Daldal, 2016). In another study, it was concluded that the first factor that the producers preferred in seed selection was yield (21.31\%) and then seed price (18.69) (Adalıoglu et al., 2017). In a study by Banerjee et al. (2007), it was stated that the second most important factor affecting seed preferences was seed prices. When the answers in terms of socio-economic variables were examined, the relationship between certified seed support and education and non- 
agricultural income was found to be statistically significant $(\mathrm{p}<0.05)$. The insufficient visibility of the support given by the middle or high school graduates is higher than that of the primary school or university graduates. While $90.6 \%$ of the secondary school graduates found the support given as insufficient, this rate was $\mathbf{7 5 . 8 \%}$ for university graduates. In the studies on education, it is not possible to use technology in a functional way without knowing the effects of innovation on society and the view of society on innovation. In a study on education, it has been determined that technological innovations should be adopted by individuals and used in innovation production (Kılıçer, 2008). According to Rogers, early majority of the novelty of innovation is more important than the late majority of the feature (Rogers, 2003). In another study, it was found that when the education level of producers is low, communication with public institutions and organizations is weak and communication with private agricultural consultants is stronger (Balbay, 2014). Education was found to be important among the factors affecting the adoption of new technologies applications and the achievement of different sources of information (Mittal and Mehar, 2016). It was determined that the level of education in the farms, access to information, positive environmental attitudes, environmental awareness and use of social networks are related to adoption rates (Prokopy et al., 2008). The level of education in the field research has been found to be effective on behavior change (Rogers, 1983; Demir, 2009). Field variables allocated to education and seed production were determined as important variables determining the efficiency of wheat seed production. In the organization of producer training and extension programs, it has been determined that the target group can be well-known and the need analysis is done well, and the efficiency of training and extension studies can be increased (Hazneci and Ceyhan, 2017).

Table 2. The effects of socio-economic characteristics on opinions of producers used comparison of certified seed supports

\begin{tabular}{|c|c|c|c|c|c|}
\hline \multicolumn{6}{|c|}{ Insufficient amount of support } \\
\hline Variable & Defination & No & Yes & Total & $\chi^{2}$ \\
\hline \multirow[t]{4}{*}{ Producers' education } & Primary & $12(19.7)$ & $49(80.3)$ & 61 & $23.42^{* *}$ \\
\hline & Middleschool & $1(1.5)$ & $66(98.5)$ & 67 & \\
\hline & High school & $9(5.7)$ & $148(94.3)$ & 157 & \\
\hline & University & $8(24.2)$ & $25(75.8)$ & 33 & \\
\hline \multirow[t]{2}{*}{ Place of residence } & Rural & $21(10.8)$ & $174(89.2)$ & 191 & 1.05 \\
\hline & City & $9(7.3)$ & $114(92.7)$ & 123 & \\
\hline \multirow[t]{2}{*}{ Off-farmincome } & No & $11(6.2)$ & $166(93.8)$ & 177 & $4.84^{*}$ \\
\hline & Yes & $19(13.5)$ & $122(86.5)$ & 141 & \\
\hline \multirow[t]{3}{*}{ Annual income status } & Low & $2(6.9)$ & $27(93.1)$ & 29 & 3.60 \\
\hline & Medium & 24 (11.7) & $181(88.3)$ & 205 & \\
\hline & High & $4(4.8)$ & $80(95.2)$ & 84 & \\
\hline Total & & $30(9.4)$ & 288 (90.6) & 318 & \\
\hline
\end{tabular}

Comparison of the opinions about the sufficiency of seed according to socio-economic characteristics is given at Table 3. As shown in Table 3, the majority of producers (95\%) stated that there was enough seed. When the answers were examined in terms of socio-economic variables, the relationship between the non-agricultural income status and opinions on seed adequacy was found to be statistically significant ( $\mathrm{p}<0.05)$. While $8.5 \%$ of non-agricultural producers stated that there was not enough seed, this ratio was $2.3 \%$ in non-agricultural producers. The importance of agricultural technology in increasing production and productivity can be realized when technologies that increase efficiency are widely used and disseminated. In a previous study, non-farm farm income was found to be effective in the adoption of agricultural technologies (Hailu et al., 2014). It has been determined that producers engaged in sustainable agriculture have more farm income compared to traditional producers (Comer et al., 1999). In another study, it was determined that the one-year increase in education level led to an increase of $2.5 \%$ depending on the possibility of the producer turning to non-agricultural income sources (Nazir et al., 2018).

The effect of socio-economic characteristics on views of alternative seed existence is shown in Table 4. When the answers were examined in terms of socio-economic variables, statistically significant relationships were found between the level of residence and income and the opinions about alternative 
seed presence ( $\mathrm{p}<0.05$ ). $26 \%$ of the inhabitants of the city were found to have no better seeds, whereas this ratio was $10.3 \%$ for rural producers. $25 \%$ of the high-income producers stated that there was no better seed, while in other producers this ratio was in the range of 13-14\%. Different results have been obtained in studies on having information about certified seed. In a study, it was found that $52.3 \%$ of the producers in Burdur province and 69.3\% in Isparta province used certified seed. In both provinces, it is determined that producers do not have sufficient knowledge about certified seed use (Gül et al., 2015). It was determined that the producers, who are in the effort to provide real efficiency in production, increased their agricultural non-agricultural and agricultural activity revenues, and the willingness to benefit from agricultural support policies increased (Topçu, 2008).

Table 3. Comparison of the opinions about the sufficiency of seed according to socio-economic characteristics

\begin{tabular}{|c|c|c|c|c|c|}
\hline \multirow[b]{2}{*}{ Variable } & \multicolumn{5}{|c|}{ Not enough certified seeds } \\
\hline & Defination & No & Yes & Total & $\chi^{2}$ \\
\hline \multirow{4}{*}{$\begin{array}{l}\text { Producers' } \\
\text { education }\end{array}$} & Primary & $59(96.7)$ & $2(3.3)$ & 61 & 1.76 \\
\hline & Middleschool & $63(94.0)$ & $4(6.0)$ & 67 & \\
\hline & High school & $150(95.5)$ & $7(4.5)$ & 157 & \\
\hline & University & $30(90.9)$ & $3(9.1)$ & 33 & \\
\hline \multirow[t]{2}{*}{ Place of residence } & Rural & $185(94.9)$ & $10(5.1)$ & 195 & 0.10 \\
\hline & City & $117(95.1)$ & $6(4.9)$ & 123 & \\
\hline \multirow[t]{2}{*}{ Off-farmincome } & No & $173(97.7)$ & $4(2.3)$ & 177 & $6.42^{*}$ \\
\hline & Yes & $129(91.5)$ & $12(8.5)$ & 141 & \\
\hline \multirow{3}{*}{$\begin{array}{l}\text { Annual income } \\
\text { status }\end{array}$} & Low & $26(89.7)$ & $3(10.3)$ & 29 & 2.95 \\
\hline & Medium & $194(94.6)$ & $11(5.4)$ & 205 & \\
\hline & High & $82(97.6)$ & $2(2.4)$ & 84 & \\
\hline Total & & $302(95.0)$ & $16(5.0)$ & 318 & \\
\hline
\end{tabular}

Table 4. Comparison of opinions about alternative seed existence according to socio-conomic characteristics.

\begin{tabular}{|c|c|c|c|c|c|}
\hline \multirow[b]{2}{*}{ Variable } & \multicolumn{5}{|c|}{ No better certified seeds } \\
\hline & Defination & No & Yes & Total & $\chi^{2}$ \\
\hline \multirow[t]{4}{*}{ Producers' education } & Primary & 48 (78.7) & $13(21.3)$ & 61 & 1.88 \\
\hline & Middleschool & $55(82.1)$ & $12(17.9)$ & 67 & \\
\hline & High school & $135(86.0)$ & $22(14.0)$ & 157 & \\
\hline & University & $28(84.8)$ & $5(15.2)$ & 33 & \\
\hline \multirow[t]{2}{*}{ Place of residence } & Rural & $175(89.7)$ & $20(10.3)$ & 195 & $13.70^{* *}$ \\
\hline & City & $91(74.0)$ & $32(26.0)$ & 123 & \\
\hline \multirow{2}{*}{ Off-farmincome } & No & $147(83.1)$ & $30(16.9)$ & 177 & 0.10 \\
\hline & Yes & $119(84.4)$ & $22(15.6)$ & 141 & \\
\hline \multirow[t]{3}{*}{ Annual income status } & Low & $25(86.2)$ & $4(13.8)$ & 29 & $6.25^{*}$ \\
\hline & Medium & $178(86.8)$ & $27(13.2)$ & 205 & \\
\hline & High & $63(75.0)$ & $21(25.0)$ & 84 & \\
\hline Total & & $266(83.6)$ & $52(16.4)$ & 318 & \\
\hline
\end{tabular}

The producers'opinions on certified seed prices are shown in Table 5. When the answers were examined in terms of socio-economic variables, the relationship between education level and seed price was found to be statistically significant $(\mathrm{p}<0.01)$. The university graduates consider the seed price to be less expensive than other producers. While $92.5 \%$ of the secondary school graduates found the seed price to be expensive, this rate was found to be $69.7 \%$ for university graduates. In a previous study on education, it was determined that producers who received training and adopted new technologies gained more rice yield per hectare. In another study on education, it was determined that the producers who were trained in agricultural production had a high potential to increase productivity in production (Nakano et al., 2018). The contribution of educated communities to agricultural development is high (Abah and Betja, 2015). 
Table 5. Opinions of Producers on seed prices with respect to socio-economic

\begin{tabular}{|c|c|c|c|c|c|}
\hline \multirow[b]{2}{*}{ Variable } & \multicolumn{4}{|c|}{ Certified Seed Expensiveness } & \multirow[b]{2}{*}{$\chi^{2}$} \\
\hline & Defination & No & Yes & Total & \\
\hline \multirow[t]{4}{*}{ Producers' education } & Primary & $5(8.2)$ & $56(91.8)$ & 61 & $13.63^{* *}$ \\
\hline & Middleschool & $5(7.5)$ & $62(92.5)$ & 67 & \\
\hline & High school & $16(10.2)$ & $141(89.8)$ & 157 & \\
\hline & University & $10(30.3)$ & $23(69.7)$ & 33 & \\
\hline \multirow[t]{2}{*}{ Place of residence } & Rural & $17(8.7)$ & $178(91.3)$ & 195 & 3.40 \\
\hline & City & $19(15.4)$ & $104(84.6)$ & 123 & \\
\hline \multirow{2}{*}{ Off-farmincome } & No & $19(10.7)$ & $158(89.3)$ & 177 & 0.14 \\
\hline & Yes & $17(12.1)$ & $124(87.9)$ & 141 & \\
\hline \multirow[t]{3}{*}{ Annual income status } & Low & $0(0.0)$ & $29(100.0)$ & 29 & 2.95 \\
\hline & Medium & $16(7.8)$ & $189(92.2)$ & 205 & \\
\hline & High & $20(23.8)$ & $64(76.2)$ & 84 & \\
\hline Total & & $36(11.3)$ & $282(88.7)$ & 318 & \\
\hline
\end{tabular}

\section{Conclusion}

Certified seed production and usage has increased steadily in recent years in Turkey. These increases have played an important role in increasing wheat yield and quality. The increase in wheat yield and quality has had a significant impact on producer, consumer and wheat industry. The majority of the producers (90.6\%) stated that the amount of support was insufficient and this was an obstacle to the use of more certified seeds. Furthermoere, producers (88.7\%) stated that certified seed prices were high. In the research area, it has been determined that the amount of certified seed treated by public and private sector institutions is sufficient. The producers (95\%) stated that they did not have any problems in obtaining certified seeds. In addition, it was found that there is no problem in finding alternative seed in the research area. Education, non-agricultural income and producer's income level were found to be important variables on the use of certified seeds. We conclude that the supports contribute to the adoption of certified seed (58.7\%), thus increase the use of certified seeds, and the gross production value while reduce the production costs. Increasing the certified seed support will contribute to enhance the yield and improve the quality of wheat. Providing the the support payments in planting period will contribute to increasing the use of certified seeds.

\section{Acknowledgment}

We would like to thank the cereal producers, agricultural institutions and organizations in Ankara where we received the primary data of the study.

\section{References}

Abah, R. C., \& Petja, B. M. (2015). The Socio-economic factors affecting agricultural development in the lower river benue basin. Journal of Biology, Agriculture and Healthcare, 5, 84-94.

Adalığlu, H. A., Akkuş, İ. C., Abay, C., \& Kart, M. Ç. Ö. (2017). Aydın ili Söke ilçesinde pamuk üreticilerinin tohum tercihlerini etkileyen faktörler. Anadolu Tarım Bilim. Der., 32, 189-196.

Engindeniz, S. \& Adanacıoğlu, H. (2011). Tarımsal üretimde etkili olan faktörlerin analitik yaklaşımla incelenmesi: Buğday örneği. TKB Türktarım Dergisi, 200, 20-28.

Aksoy, A., Demir, N., Kaymak, H. Ç., \& Sarı, M. M. (2017). Seed sector of Turkey in terms of sustainable agriculture. Atatürk Universty Journal of the Agricultural Faculty, 48, 133-138.

Anonymous. (2001). Plant production specialized commission report of seed sub-commission. DPT, Eighth Five-Year Development Plan, Ankara.

Anonymous. (2018). Cereal Report. Turkish Grain Board. http://www.tmo.gov.tr/HububatRaporu Erişim tarihi: 13.11.2018.

Awotide, B. A., Awoyemi, T. T., Diagne, A., \& Ojehomon V. T. (2011). Impact of access to subsidized certified improved rice seed on income: Evidence from rice farming households in Nigeria. OIDA International Journal of Sustainable Development, 2, 43-60. 
Balabanlı, C., Cirit, Y., Kayacan, S., Bıçakçı, E., \& Yüksel, O. (2016). Yem Bitkileri Tarımında Üretici Davranışlarının Belirlenmesi: Isparta ili örneği. Tarla Bitkileri Merkez Araştırma Enstitüsü Dergisi, 25 (Özel say1-2), 259-264.

Balbay, D. (2014). Marmara bölgesinde örtüaltı tarımı geliştirme koşul ve olanakları üzerine bir araştırma. (Yüksek Lisans Tezi), Namık Kemal Üniversitesi Fen Bilimleri Enstitüsü, Tarım Ekonomisi A.D. Tekirdağ, Türkiye.

Banerjee, S., Ban, H. D., \& Martin, S. W. (2007). Effects of seed and farm characteristics on cottonseed choice: a choice-based conjoint experiment in the Mississippi Delta. Journal of Agricultural and Applied Economics, 39, 657-669.

Başaran, C., \& Engindeniz, S. (2015). Analysis of input use efficiency in green pepper production: A case study for Izmir Province. Turkish Journal of Agricultural Economics, 21, 7784.

Bishaw, Z., Niane, A. A., \& Gan, Y. (2007). Quality seed production. Springer, lentil: An Ancient Crop for Modern Times, 349-383.

Boyacı, M. \& Yıldız, Ö. (2014). Tarımsal Yayım Örgütlerinde Kurum Kültürü. Ege Üniversitesi Ziraat Fakültesi Dergisi, 51, 125-132.

Cevher, C. (2015, Eylül). Buğday çeşitlerinde kalite sorunları ve çözüm yollart: Orta Anadolu örneği Paper presented at the 11. Tarla Bitkileri Kongresi, Çanakkale.

Cevher, C. \& Altunkaynak, B. (2019, June). Investigation of socio-economic characteristics of wheat producers on certified seed use: The Case of Ankara Province Paper presented at the International Conference on Agronomy and Food Science and Technology, İstanbul.

Comer, S., Ekanem, E., Muhammad, S., Sing, S. P., \& Tegegne, F. (1999). Sustainable and conventional farmers: a comparison of socio-economic characteristics, attitude and beliefs. Journal of Sustainable Agriculture, 15, 29-45.

Daldal, N. (2016). Tarımsal desteklemelere üreticilerin yaklaşımı: Tekirdă̆ ili örneği. (Yüksek Lisans Tezi), NKÜ., Fen Bilimleri Enstitüsü Tarım Ekonomisi A.D. Tekirdağ, Türkiye.

Demir, N. (2009). Destekleme Politikalarının Hayvancllı Sektörü Üzerine Etkilerinin Bölgesel Karşılaş̧ırmalı Analizi. (Doktora Tezi), Atatürk Üniversitesi, Fen Bilimleri Enstitüsü Tarım Ekonomisi A. D. Erzurum, Turkiye.

Erdem, B. (2012). Trakya bölgesinde buğday, ayçiçeği ve çeltiğin üretim ve pazarlama sorunlarının analizi. (Doktora Tezi), Namık Kemal Üniversitesi Fen Bilimleri Enstitüsü Tarım Ekonomisi A. D. Tekirdă̆, Türkiye.

Erdem, E., \& Yücel, A. G. (2015). Türk tarim sektöründe tohumluk kullanimi ve verimlilik ilişkisi üzerine bir uygulama. Bilgi Ekonomisi ve Yönetimi Dergisi, 9, 90-106.

Engin, A. (2015). Seed development of the future of forage crops. Turkey Seed Industry Association, $14,3$.

Gül, H., Gül, M., Acun, S., Türk Aslan, S., Öztürk, A., Kara, B., \& Akman, Z. (2015). Tarım İşletmelerinde Buğday Tohumu Kullanımı ve Sorunları: Burdur ve Isparta İlleri Örneği. Türk Tarım-Gida Bilim ve Teknoloji Dergisi, 3, 732-741.

Jaffee, S., \& Srivastava, J. (1994). The Roles of The Private and Public Sectors In Enhancing The Performance of Seed Systems. The World Bank Research Observer, 9, 97-117.

Hailu, B. K., Abrha, B. K., \& Weldegiorgi, K. A. (2014). Adoption and impact of agricultural technologies on farm income: Evidence from southern tigray, Northern Ethiopia. International Journal of Foodand Agricultural Economics, 2, 91-106.

Hennessy, T. \& O'Brien, M. (2008). Is off-farm income driving on-farm investment? Journal of Farm Management 13, 235-246.

Hazneci, K., \& Ceyhan, V. (2017). TR83 Bölgesinde buğday tohumluğu üretiminde teknik etkinlik ve etkinliği belirleyen faktörler. Anadolu Tarım Bilimleri Dergisi, 32, 181-188.

İpekçioğlu, Ş., Bayraktaş, M. S., Büyükhatipoğlu, Ş., \& Monis, T. (2014, September). Şanlıurfa ve Mardin Illlerinde Bü̆day Yetiştiriciliği Yapan Çiftçilerin Çeşit Seçimindeki Bilgi Düzeylerinin Belirlenmesi Paper presented at the XI. Ulusal Tarım Ekonomisi Kongresi, Samsun.

Kaynak, O. \& Boz, İ. (2015). Adoption and diffusion of some cotton varieties developed by the east Mediterranean cross region agricultural research institute. J of Bahri Dagdas Crop Research, 3, 26-34.

Kızılaslan, H. (2004). Wheat Dünya'da ve Türkiye'de Buğday Üretimi ve Uygulanan Politikaların Karşılaştırılması. GOÜ. Ziraat Fakültesi Dergisi, 21, 23-38. 
K1lıçer, K. (2008). Teknolojik yeniliklerin yayilmasini ve benimsenmesini arttiran etmenler. Anadolu Üniversitesi Sosyal Bilimler Dergisi, 8, 209-222.

Kronstad, W. E. (1998). Agricultural development and wheat breeding in the $20^{\text {th }}$ Century. Wheat: Prospects for Ciobalimprovement 1-10.

La Due, E. L., Miller, L. H., \& Kwiatkowski, J. H. (1991). Investment behavior and farm business expansion. Review of Agricultural Economics, 13, 73-84.

Lanteri, S. \& Quagliotti, L. (1997). Problems related to seed production in the African region. Euphytica, 96, 173-183.

Laurance, W. F., Sayer, J., \& Cassman, K. G. (2014). Agricultural expansion and its impacts on tropical natüre. Trends in Ecology and Evolution, 29, 107-116.

Mittal, S., \& Meher, M. (2016). Socio-economic factors affecting adoption of modern information and communication technology by farmers in India: analysis using multivariate probit model. The Journal of Agricultural Education and Extension, 22, 199-212.

Nakano, Y., Tanaka, Y., \& Otsuka, K. (2018). Impact of training on the intensification of rice farming: evidence from rainfed areas in Tanzania. The journal of the International Association of Agricultural Economics, 49, 193-202.

Nazir, A., Li, G., Inayat, S. Iqbal, M. A., Humayoon, A., \& Akhtar, S. (2018). Determinants for income diversification by farm households in Pakistan. The J of Animal and Plant Sci., 28, 1163-1173.

Olgun, M., Erdoğan, S., Kutlu, İ., Ayter, N. G., \& Başçiftçi, Z. B. (2012). Buğday (Triticum aestivum L.) ve arpanın (Hordeum vulgare L.) orta anadolu bölgesi'ndeki üretim potansiyeli. Ziraat Fakültesi Dergisi - Süleyman Demirel Üniversitesi, 7, 81-92.

Osteen, C., Gottlieb, J., \& Vasavada, U. (2012). Agricultural resources and environmental indicators. United States Department of Agriculture, Economic Information Bulletin Number, 98.

Prokopy, L. S., Floress, K., Klotthor-Weinkauf, D., \& Baumgart-Gets, A. (2008). Determinants of agricultural best management practice adoption: Evidence from the literatüre. The Journal of Soil and Water Conservation, 63, 300-311.

Rogers, M. E. (2003). Diffusion of Innovations (Fifth Ed.). New York, USA.

Sofijanova, E., Kletnikoski, P., Dimovska, V., \& Dimitrovski, Z. (2012). Comparative economic analysis of wheat production using certified and uncertified seed: The case of ovcepole region in republic of Macedonia. Scientific works of uft "Food Science, Engineering and Technologies”, 510, 922926.

Şahin, A., Meral, Y., \& Can, M. (2013). Türkiye Tohumculuk Sektörünün Analizi. Çankırı Karatekin Üniversitesi Sosyal Bilimler Enstitüsü Dergisi, 4, 73-88.

Şehirali, S. \& Özgen, M. (2013). Plant Breeding. Ankara, TURKEY: Ankara University, Faculty of Agriculture Publications: 1582, Anakara University Printing.

Tester, M. \& Langridge, P. (2010). Breeding technologies to increase crop production in a changing world. Science, 327, 818-822.

Topçu, Y. (2008). Çiftçilerin tarimsal destekleme politikalarindan faydalanma istekliliğinde etkili faktörlerin analizi: Erzurum ili örneği. AÜ., Ziraat Fakültesi Dergisi, 21, 205-212.

Tuğay, M. E. (2012). Türk tarımında bitkisel üretimi artırma yolları. Tarım Bilim. Araş. Der., 5, 01-08.

Yamane, T. (2001). Temel Örnekleme Yöntemleri. İstanbul, Turkiye: Literatür Yayınc1lık.

Yağdı, K., Yılmaz, K., Sezer, N., Aydemir T., \& Bağc1, S. A. (2010, Ocak). Türkiye’de tarla bitkileri tohumluk üretimi ve kullanımı ile tohumculuk sisteminin genel değerlendirilmesi Paper presented at the Ziraat Mühendisliği VII. Teknik Kongresi, Ankara.

Yüksel, M. (2009). Köy-KOP'a üye olan ve süt siğgrccllı̆̆ y yapan işletmeler ile üye olmayıp süt siğırcıllğg yapan işletmelerin tarımsal yeniliklerin benimsenmesi açısından karşılaştırılması. Yüksek Lisans Tezi, Ç.Ü.,Fen Bilimleri Enstitüsü Tarım Ekonomisi A.D. Adana, Turkey. 